\title{
Identifying Parenting Practices: An Initial Step in Setting Up Parenting Program in School
}

\author{
ZAHYAH HANAFI \\ Faculty of Cognitive Sciences and Education \\ Universiti Utara Malaysia
}

\begin{abstract}
The purpose of this study was to identify the levels of parenting practices among Malay and Chinese parents as perceived by their children. A total of 217 students responded to a questionnaire with items pertaining to their mothers' and fathers'demandingness and responsiveness practices. Findings revealed most of the Malay and Chinese parents in this study were perceived by their children to be low in demandingness and responsiveness. The only difference reported was between mothers' and fathers' demandingness. The response to each item in the demandingness and responsiveness measurement would be a guide to what should be included in the parenting course program. Implications for further research were also discussed.
\end{abstract}

\begin{abstract}
ABSTRAK
Tujuan kajian ini ialah untuk mengenal pasti tahap amalan keibubapaan di kalangan ibu bapa Melayu dan Cina sebagaimana dilihat oleh anak-anak. Sejumlah 217 orang pelajar telah menjawab soal selidik yang mengandungi pernyataan tentang amalan desak dan respon ibu bapa mereka. Dapatan menunjukkan kebanyakan responden melihat ibu bapa mereka mempunyai tahap rendah dari segi desak dan respon terhadap mereka. Jawapan kepada setiap pernyataan di bahagian desak dan respon akan menjadi panduan terhadap isi kandungan yang perlu ditekankan dalam program keibubapaan kelak. Cadangan untuk kajian selanjutnya juga dibincangkan.
\end{abstract}

\section{INTRODUCTION}

The importance of parental involvement among Malaysian parents is consistently emphasized by various Ministries (Saufi, 2002; Rohaniza, 2002; Kadir \& Salina, 2002), non-government organizations (Mohd Zamir, 2002; Noormala, 2002) and mass media (Sumitha, 2002; Loong, 2002). To handle this issue, the Ministry of Women and Family Development was set up to promote "the interest of women and their participation in national development and to coordinate family development programs. (www.ilo.org/public/ english/employment/gems/eeo/law/malaysia/ mnu.htm).
In addition to the effort made by the government, Malaysian researchers have dealt with issues pertaining to parents' involvement in children's learning (Noran Fauziah, Jahara, Nuraini, \& Zahyah, 2000; Wee Beng Neo, 1999), thus, reflecting the awareness and importance of parents' role in the development of children, especially for cognitive (Awang Koding \& Tengku Sarina Aini, 2003; Azizan, 2003; Fatimah, Khaizir, $\&$ Mustafa, 2003) and psychological development (Fatimah \& Azman, 2003). The findings in these studies revealed the existing social and learning problems among our children (Lokman, 2001; "Saving the troubled," 2002; Nik Safiah, 2002). 
These findings also show there is a relationship between parents' involvement and children's development (Steinberg, L, Dornbusch, \& Darling, 1992; Halle, Kurtz-Costes, \& Mahoney, 1997; McBride-Chang \& Chang, 1998; Hong \& Lee, 2000; Cooper, Kristina, Barbara, \& Lindsay, 2001) thus, it can be assumed that having parenting course programs to educate parents on correct parenting skills may instill positive behaviors and learning attitudes in children.

\section{Statement of Problem}

The existing literature on parenting practices in Malaysia seems to be growing as more emphasis is being focused on this area by the government and the public. However, what seems lacking in the literature is the implementation of appropriate programs to cater for the needs of parents based on the findings by researchers. Many researchers have presented their findings on parental involvement practices but few have implemented the suggestions forwarded in their studies (Fatimah Abdullah et al., 2003: Fatimah Yusooff et al., 2003; Noran Fauziah Yaakub et al., 2000).

Various ministries and non-government organizations (NGO) in Malaysia have conducted parenting courses to instill awareness among Malaysian parents of their role in child development and the effective parenting skills they need to practice. However, few of these ministries and NGOs have reported on how to set up parenting programs in terms of its implementation and effectiveness. Thus, there is a need to close this gap by initiating a study to identify the needs of parents and the implementation of a parenting course program. The present study is an initial step in addressing this vital issue.

This study will try to answer the following research questions:

(1) What are the levels of demandingness and responsiveness among Malay and Chinese mothers and fathers as perceived by their children?

(2) Do Malay and Chinese mothers and fathers differ in their demandingness and responsiveness towards sons and daughters?
The study will investigate the parenting practices among Malay and Chinese parents as perceived by their children. The parenting practices will be categorized as levels-low, high, and undecided. Each level will reflect different parenting practices. The findings will form the contents for the parenting course specifically tailored to enhance parenting practices among parents with different parenting styles.

Concerning parenting practices, there is likely to have variations in parents' behaviors in raising children. Research findings show crosscultural differences in parenting practices (Best \& House, 1994; Hanson \& Lynch, 1990; Julian, McKenry, \& McKelvey, 1994). In most cultures, values and ideas are transmitted during childrearing. As such, interpersonal relations, social participation, and role-specific modeling are subsequently passed on to the next generation of parents (Kaplan, Liu, \& Kaplan, 2000). Thus, cultural context may to a certain extent influence child-rearing practices.

In addition to culture, other factors such as gender of the parent (Paulson \& Sputa, 1996; Pipp, Shaver, Jennings, Lamborn, \& Fisher, 1985; Vitulli \& Richardson, 1998; Shek, 1999, 1998) may have an influence on how mothers and fathers raised their children. However, in Malaysia, generally Malay parents' influences on children are determined through "heritage" (genetically) and ecological process (Wan Halim Othman, 1993). In other words, Malay parents tend to inherit the parenting practices from their parents. In addition, parents were found to differ in their parenting practices towards sons and daughters (Block, 1983; Lytton \& Romney, 1991; Shek, 2000). Thus, all these differences are influenced by culture as well as ecological factors.

This study draws the attention to these differences when planning parenting course programs as disregarding these differences may hinder the implementation of a successful parenting course.

\section{METHODOLOGY}

\section{Population}

The population comprised secondary school students, specifically Fifth Formers in one 
particular school. The respondents were 217 students (141 Malays and 76 Chinese). The school is selected to start a parenting course program.

Thus, the findings and the parenting course would only be meant for Malay and Chinese parents in this selected school and should not be generalized to parents in other schools. Only Malay and Chinese students were selected for this study. Indian students were not present in these classes. Only respondents who lived with both biological mothers and fathers were selected for this study. Those living in hostels were excluded.

The survey was only performed on students and not their parents. This was to ensure the findings reflect only children's perceptions of their parents' parenting practices. Children were found to be better in perceiving their parents' involvement than parents themselves (Paulson, Hill, \& Holmbeck, 1991; Paulson, 1994a). In addition, parents were reported to perceive themselves as more involved in parenting than their children (Schwarz, Barton-Henry, \& Pruzinsky, 1985). Thus, children's perceptions would be more appropriate for this study.

\section{Instrumentation}

The instrument to assess parenting practices was adopted from the "Parenting Style Scale" (Paulson, 1994b), designed to assess both maternal and paternal demandingness and responsiveness from children's perspectives, as defined by Baumrind $(1967,1971)$ and Maccoby and Martin (1983).

There were ten items to elicit information on rules and discipline strategies for the demanding scale and eight items pertaining to warmth and nurturance for the responsiveness scale. Each item had a 5-point Likert scale, ranging from $1=$ strongly disagree to $5=$ strongly agree. Six of the demandingness items and four of the responsiveness items were negatively worded. These items were then recoded. To determine the levels of demandingness and responsiveness, the mode technique was applied to identify the most frequently cited anchor. This was done by inspection rather than by computation. The levels were categorized into: $1=$ low, $3=$ undecided, 5 $=$ high.
In this study the categorical scale was used to reflect all respondents assigned to the same category. The respondents would be alike with respect to some of the demandingness and responsiveness attributes (Nunnally, 1978). The anchor $3=$ undecided, was included in the ordinal scale as there could be some respondents who actually felt that way and did not wish to be forced into agreeing or disagreeing (Ary, Jacobs, \& Razavieh, 2002). The "undecided" category could also refer to respondents who were unaware of the parental behaviors of their parents and thus, were undecided whether the behavior existed or not. Most social and behavioral sciences and education measurements were at best ordinal even though most researchers treat it as interval (Mason \& Bramble, 1997).

The researcher conducted the survey twice in the school. The first session saw students responding to items pertaining to mothers' involvement while the second session was on fathers'. This was to ensure the students were not confused when responding to their respective parent.

The categorical nature of the data (Hair, Anderson, Tatham, \& Black, 1998) would be best analyzed with non-parametric tests, where assumptions were made on the chosen sample and not on the wider population (Cohen, Manion, \& Morrison, 2001). In addition, non-parametric tests have the advantage of being tailored to particular individual circumstances, in this case, three different levels of parenting practices (Cohen et al. 2001).

\section{FINDINGS AND DISCUSSION}

From a total of 217 respondents, $84(38.7 \%)$ were males and $133(61.3 \%)$ were females (Table 1). In terms of ethnic group, there were more Malays (141) compared to Chinese (76). The data would be useful in determining the number of parents in terms of gender and ethnicity who would be participating in the program. The program could either be divided according to gender or ethnic groups. 
Table 1

Frequency Distribution and Percentage of Respondents

\begin{tabular}{cccc}
\hline & Boys & Girls & Total \\
\hline Malays & 39 & 102 & 141 \\
& $(27.7)$ & $(72.3)$ & \\
Chinese & 45 & 31 & 76 \\
& $(59.2)$ & $(40.8)$ & \\
\hline & 84 & 133 & 217 \\
\hline
\end{tabular}

Note: Figures in parentheses indicate valid percentages

Research Question 1: What are the levels of demandingness and responsiveness among Malay and Chinese mothers and fathers as perceived by their children?

Table 2 presents the levels of demandingness among Malay and Chinese parents. Overall, parents' demandingness was low, irrespective of gender. However, there were differences between mothers' and fathers' demandingness $\left(\chi^{2}=53.008\right.$, d.f. $\left.=4, \mathrm{p}=.001\right)$. For the low category of demandingness, more fathers were perceived lower $(53.4 \%)$ compared to mothers $(52.5 \%)$. In the high category of demandingness, more fathers were rated higher (13\%) compared to mothers $(12 \%)$. In the undecided category, fewer fathers were were rated low $(33.6 \%)$ compared to mothers $(35.5 \%)$. In terms of ethnic, few Malay mothers' and fathers' demandingness were reported were rated low compared to Chinese mothers' and fathers'.

Table 3 presents the levels of responsiveness among Malay and Chinese parents. Both ethnic groups were low in responsiveness. There was no significant difference between Malay and Chinese mothers responsiveness $\left(\chi^{2}=\right.$ 5.112 , d.f. $=4, \mathrm{p}=.276$ ). Similarly, there was no significant difference between Malay and Chinese fathers responsiveness $\left(\chi^{2}=3.273\right.$, d.f. $=4, \mathrm{p}=$ $.513)$.

Thus, the findings show that there were significant differences between mothers and fathers demandingness ( $\mathrm{p}<.05)$. Generally, mothers were perceived to be more involved in child-rearing compared to fathers. Therefore, this finding suggests that the program could separate mothers from fathers. The differences in parenting practices between them could be due to their own belief and understanding of their role as a parent. Therefore, each parent would need a different approach during the program.

Similarly, there were differences in the way Malay and Chinese mothers placed demandingness on their children ( $\mathrm{p}<.05)$. Again, it would be advisable to group mothers according to ethnic groups.

Research question 2: Do Malay and Chinese mothers and fathers differ in their demandingness and responsiveness towards sons and daughters?

Overall, there was no difference between mothers' and fathers' approach in child-rearing practices towards sons and daughters $(\mathrm{p}>.05)$. There was also no difference between Malay and Chinese mothers' and fathers' demandingness and responsiveness towards sons and daughters ( $\mathrm{p}>$ $.05)$

Table 4 presents an overall report of mothers' and fathers' parenting style. The majority of the parents in this study were reported to be more inclined towards a 'neglect' style of parenting. Parents who adhered to this type of parenting showed no concern for either the child's 
Table 2

Frequency Distribution and Percentage of Demandingness

\begin{tabular}{|c|c|c|c|c|}
\hline & Low & High & Undecided & Total \\
\hline Malay mothers & $\begin{array}{l}79 \\
(56.0)\end{array}$ & $\begin{array}{l}18 \\
(12.8)\end{array}$ & $\begin{array}{l}44 \\
(31.2)\end{array}$ & 141 \\
\hline Chinese mothers & $\begin{array}{l}35 \\
(46.0)\end{array}$ & $\begin{array}{l}8 \\
(10.5)\end{array}$ & $\begin{array}{l}33 \\
(43.4)\end{array}$ & 76 \\
\hline Mothers & $\begin{array}{l}114 \\
(52.5)\end{array}$ & $\begin{array}{l}26 \\
(12.0)\end{array}$ & $\begin{array}{l}77 \\
(35.5)\end{array}$ & 217 \\
\hline Malay fathers & $\begin{array}{l}83 \\
(58.9)\end{array}$ & $\begin{array}{l}18 \\
(12.8)\end{array}$ & $\begin{array}{l}40 \\
(28.4)\end{array}$ & 141 \\
\hline Chinese fathers & $\begin{array}{l}33 \\
(43.4)\end{array}$ & $\begin{array}{l}10 \\
(13.2)\end{array}$ & $\begin{array}{l}33 \\
(43.4)\end{array}$ & 76 \\
\hline Fathers & $\begin{array}{l}116 \\
(53.4)\end{array}$ & $\begin{array}{l}28 \\
(13)\end{array}$ & $\begin{array}{l}73 \\
(33.6)\end{array}$ & 217 \\
\hline
\end{tabular}

Note: Figures in parentheses indicate valid percentages

needs or the child's behavior and were disengaged from parenting (Baumrind, 1967; 1971) and unsupervised behavior with no concern for their children's welfare (Lamborn, Mounts, Steinberg, $\&$ Dornbusch, 1991). Thus, these parents need to be informed of the importance of parenting in terms of its contributions towards social and educational development. In addition, a high percentage of students were unable to perceive their parents' parenting practices clearly.

"Neglect" and "undecided" parenting style reflected parents to be either not consistent in their practices or entirely uninvolved in their children's life (Baumrind, 1968, 1971). As a result, children were unable to perceive the child-rearing practices clearly. In this case, these parents need to be educated in terms of the different types of positive parenting skills and how to implement them during child-rearing.

The responses to the individual items on mothers' and fathers' demandingness were shown in Tables 5 and 6 respectively. Tables 7 and 8 show mothers' and fathers' responsiveness. The items on both scales were presented as low, undecided, and high to indicate the level of practice. The responses to the items reflect either positive or negative practices. These items would be included in the contents of the parenting skill program, specifically tailored to instill effective demandingness and responsiveness practices parents need to know. More emphasis could be placed on those items that revealed low practices. Items 1, 2, 5, and 7 (Tables 5 and 6) had high percentages of agreement, thus reflecting negative practices of mothers' and fathers' as perceived by their children. These items reflected mothers' and fathers' belief in autonomy as these practices allowed children to do as they pleased. The children were not punished if they did not follow the rules and they were allowed to do as they pleased with no one to question their actions. These findings suggest the need to include practices to discipline children as such parents need to be told the consequences of not enforcing 
Table 3

Frequency Distribution and Percentage of Responsiveness

\begin{tabular}{|c|c|c|c|c|}
\hline & Low & High & Undecided & Total \\
\hline Malay mothers & $\begin{array}{l}51 \\
(36.1)\end{array}$ & $\begin{array}{l}39 \\
(27.7)\end{array}$ & $\begin{array}{l}51 \\
(36.2)\end{array}$ & 141 \\
\hline Chinese mothers & $\begin{array}{l}28 \\
(36.8)\end{array}$ & $\begin{array}{l}14 \\
(18.4)\end{array}$ & $\begin{array}{l}34 \\
(44.8)\end{array}$ & 76 \\
\hline Mothers & $\begin{array}{l}79 \\
(36.4)\end{array}$ & $\begin{array}{l}53 \\
(24.4)\end{array}$ & $\begin{array}{l}85 \\
(39.2)\end{array}$ & 217 \\
\hline Malay fathers & $\begin{array}{l}41 \\
(28.8)\end{array}$ & $\begin{array}{l}40 \\
(28.2)\end{array}$ & $\begin{array}{l}61 \\
(43.0)\end{array}$ & 142 \\
\hline Chinese fathers & $\begin{array}{l}20 \\
(26.7)\end{array}$ & $\begin{array}{l}13 \\
(17.3)\end{array}$ & $\begin{array}{l}42 \\
(56.0)\end{array}$ & 75 \\
\hline Fathers & $\begin{array}{l}61 \\
(28.1)\end{array}$ & $\begin{array}{l}53 \\
(24.4)\end{array}$ & $\begin{array}{l}103 \\
(47.5)\end{array}$ & 217 \\
\hline
\end{tabular}

Note: Figures in parentheses indicate valid percentages

Table 4

Frequency Distribution and Percentage of Parenting Style

\begin{tabular}{lllllll}
\hline & ave. & author. & perm. & neg. & und. & total \\
\hline Mothers & 11 & 9 & 29 & 53 & 115 & 217 \\
& $(5.1)$ & $(4.1)$ & $(13.4)$ & $(24.4)$ & $(53.0)$ & \\
Fathers & 18 & 4 & 29 & 46 & 120 & 217 \\
& $(8.3)$ & $(1.8)$ & $(13.4)$ & $(21.2)$ & $(55.3)$ & \\
\hline Parents & 29 & 13 & 58 & 99 & 235 & 434 \\
& $(6.7)$ & $(3.0)$ & $(13.4)$ & $(22.8)$ & $(54.1)$ & \\
\hline
\end{tabular}

Note: Figures in parentheses indicate valid percentages

ave. $=$ authoritative

author. = authoritarian

perm. $=$ permissive

neg. $=$ neglect

und. $=$ undecided 
Table 5

Frequency Distribution and Percentage of Demandingness Items for Mothers (\%)

\begin{tabular}{|c|c|c|c|}
\hline Item & Disagree & Undecided & Agree \\
\hline $\begin{array}{l}\text { 1. It is okay with my mother if I do not } \\
\text { follow certain rules. }\end{array}$ & 10.1 & 47.1 & 42.8 \\
\hline $\begin{array}{l}\text { 2. When I do something that is wrong, my } \\
\text { mother usually does not punish me. }\end{array}$ & 18.9 & 28.6 & 52.5 \\
\hline 3. I think my mother disciplines me a lot. & 12.4 & 31.3 & 56.3 \\
\hline $\begin{array}{l}\text { 4. My mother usually wants to know } \\
\text { where I am going. }\end{array}$ & 2.8 & 5.5 & 91.7 \\
\hline 5. My mother gives me a lot of freedom. & 24.0 & 25.8 & 50.2 \\
\hline $\begin{array}{l}\text { 6. My mother makes most of the decisions } \\
\text { about what I am allowed to do. }\end{array}$ & 4.2 & 27.2 & 68.6 \\
\hline $\begin{array}{l}\text { 7. My mother lets me do pretty much } \\
\text { what I want without questioning my } \\
\text { decisions. }\end{array}$ & 7.4 & 19.4 & 73.3 \\
\hline $\begin{array}{l}\text { 8. My mother has few rules for me to } \\
\text { follow. }\end{array}$ & 36.4 & 32.8 & 29.9 \\
\hline $\begin{array}{l}\text { 9. My mother expects me to be home } \\
\text { a certain time after school or in the } \\
\text { evening. }\end{array}$ & 17.9 & 25.3 & 56.8 \\
\hline $\begin{array}{l}\text { 10. My mother sometimes tells me that } \\
\text { her decisions should not be questioned. }\end{array}$ & 35.1 & 40.2 & 24.5 \\
\hline
\end{tabular}

them. Similarly, Items 3 and 5 (Tables $7 \& 8$ ) reflected negative practices of mothers' and fathers' responsivenes towards their children. Children perceived their parents were not interested in listening to their problems and did not praise them when they did well.

The responses to the parenting items could be used by the school to categorize the parents into the three levels - low, high and undecided. Therefore, a group of parents attending the program would have similar parenting practices based on the category they were in (i.e. authoritative, authoritarian, permissive, undecided). This would make it easier for the school to handle one category of parents at a time. It would also be easy to handle the problems and propose solutions as all the parents in the same category may possibly face similar situations. 
Table 6

Frequency Distribution and Percentage of Demandingness Items for Fathers (\%)

\begin{tabular}{lccc}
\hline Item & Disagree & Undecided & Agree \\
\hline $\begin{array}{l}\text { 1. It is okay with my father if I do not follow } \\
\text { certain rules. }\end{array}$ & 13.7 & 42.9 & 43.4 \\
$\begin{array}{l}\text { 2. When I do something that is wrong, my } \\
\text { father usually does not punish me. }\end{array}$ & 19.4 & 30.0 & 50.6 \\
3. I think my father disciplines me a lot. & 8.7 & 25.8 & 65.5 \\
4. My father usually wants to know where I am going. & 6.5 & 10.6 & 82.9 \\
$\begin{array}{l}\text { 5. My father gives me a lot of freedom. } \\
\text { 6. My father makes most of the decisions } \\
\text { about what I am allowed to do. }\end{array}$ & 24.8 & 27.7 & 47.5 \\
$\begin{array}{l}\text { 7. My father lets me do pretty much } \\
\text { what I want without questioning my decisions. }\end{array}$ & 18.4 & 39.2 & 42.4 \\
8. My father has few rules for me to follow. & 43.8 & 35.5 & 20.7 \\
9. My father expects me to be home \\
a certain time after school or in the evening.
\end{tabular}

Table 7

Frequency Distribution and Percentage of Responsiveness Items for Mothers (\%)

\begin{tabular}{lccc} 
Item & Disagree & Undecided & Agree \\
\hline $\begin{array}{l}\text { 1. My mother sometimes criticizes me for what I do. } \\
\text { 2. My mother encourages me to talk with her about }\end{array}$ & 44.5 & 36.7 & 18.8 \\
$\quad \begin{array}{l}\text { things. } \\
\text { 3. My mother would rather I not tell her my }\end{array}$ & 8.3 & 20.2 & 68.7 \\
troubles.
\end{tabular}


(continued)

\begin{tabular}{lccc}
\hline Item & Disagree & Undecided & Agree \\
\hline $\begin{array}{l}\text { 4. My mother expects me to do what she says } \\
\text { without having to tell me why. }\end{array}$ & 37.0 & 35.9 & 29.1 \\
$\begin{array}{l}\text { 5. My mother seldom praises me for doing well. } \\
\begin{array}{l}\text { 6. My mother believes I have a right to my own } \\
\text { point of view. }\end{array}\end{array}$ & 7.9 & 32.7 & 59.4 \\
$\begin{array}{l}\text { 7. My mother takes an interest in my activities. } \\
\text { 8. My mother usually tells me the reasons for rules. }\end{array}$ & 14.2 & 38.3 & 40.3 \\
\hline
\end{tabular}

Table 8

Frequency Distribution and Percentage of Responsiveness Items for Fathers (\%)

\begin{tabular}{|c|c|c|c|}
\hline Item & Disagree & Undecided & Agree \\
\hline 1. My father sometimes criticizes me for what I do. & 48.8 & 34.6 & 16.6 \\
\hline $\begin{array}{l}\text { 2. My father encourages me to talk with } \\
\text { him about things. }\end{array}$ & 9.7 & 33.6 & 56.7 \\
\hline 3. My father would rather I not tell him my troubles. & 11.1 & 37.3 & 51.6 \\
\hline $\begin{array}{l}\text { 4. My father expects me to do what he } \\
\text { says without having to tell me why. }\end{array}$ & 40.5 & 38.2 & 20.3 \\
\hline 5. My father seldom praises me for doing well. & 22.1 & 30.9 & 46.8 \\
\hline $\begin{array}{l}\text { 6. My father believes I have a right to my own point } \\
\text { of view. }\end{array}$ & 6.5 & 33.6 & 59.9 \\
\hline 7. My father takes an interest in my activities. & 11.7 & 41.3 & 47.0 \\
\hline 8. My father usually tells me the reasons for rules. & 10.6 & 39.6 & 49.8 \\
\hline
\end{tabular}

Thus, when preparing the contents for the types of practices that need to be included in the course program, these items could be used as a guide. The items that have more than $50 \%$ responses may be highlighted as those that parents have been consistently practising. On the other hand, the items that are perceived less than 50\% show that, parents need to put in more effort to 
ensure they are perceived clearly by their children. While items on the 'undecided' category, items 2, 3, 6 and 7 (Table 7) and items 2, 3, and 6 (Table 8) on responsiveness have more than $50 \%$ responses on agreement. Again, these items are perceived clearly by the children. On the other hand, parents need to be informed that these practices have to be part of their child-rearing practises. Different ways of transmitting these practices need to be demonstrated to parents. In addition, parents need to know the importance of these practices and their influence on child development.

\section{Recommendations}

In an effort to initiate parenting programs in the school, the school needs to plan and implement the programs so as to ensure maximum results will be attained. It will be best to invite certain parties to help in the running of the program (Epstein, 1995). For example, the first step will be to invite researchers to conduct a study (as was undertaken by the researcher) to identify parents who will be participating in the course program. The results of this study will provide a clearer picture on the different levels of practices among parents (Noller \& Taylor, 2001). Programs to be implemented should not be based on a general assumption of parents' child-rearing practices, as the results of this study and others (Seginer, 1983) have indicated that parents with different levels of SES will have different levels of parenting skills. For example, parents who are low in demandings or responsiveness need to be told that they need to constantly instill these practices in their children. Parents need to be taught when, what, and how to instill these practices.

Most parenting programs assume that parents are of similar involvement level, irrespective of their SES. Thus, such programs may not benefit certain parents and eventually, will fail to achieve their objectives. In addition, constant evaluation should be conducted to assess the effectiveness of the program.

Once a parenting program at school is well organized, it will reflect the school's concern on how parents raise their children.

\section{CONCLUSION}

This study was initiated prior to the implementation of a parenting course program in a school. It was important such a study was conducted to identify the various parenting practices among parents. The findings would ensure that the course was set up for a group of parents with similar parenting practices. This would be a more effective way of handling a parenting course. The school should never assume that all parents have low parenting skills. As shown by the findings, parents differed in certain aspects of child-rearing practices based on their belief and understanding.

The findings showed that generally, Malay and Chinese parents in the school studied had poor parenting practices. Even though the purpose of the study was not to categorize parents into different parenting styles, it would be informative to know that the parents in this study were generally of the 'neglect' type where they were low in demandingness as well as responsiveness. According to Baumrind (1967, 1971) parents who adhered to this type of parenting showed no concern to either the child's needs or the child's behavior and were disengaged from parenting. Studies have shown parents who neglect and fail to monitor their children's behavior tend to produce children with problems relating to truancy and alcoholism in adolescence and adulthood (Lamborn, Mounts, Steinberg, \& Dornbusch, 1991). The findings should be looked upon as a reflection of parents' involvement in their children's lives. If effective measures are not taken by the school to enhance parents' awareness in these aspects then there is a possibility problematic behaviors may erupt from the students in the sample. Further studies on parenting practices should be conducted to investigate the relationship between poor parenting practices and their effects on child's development. Therefore, schools should look into parents parenting practices as this may to a certain extent indicate the type of child that enters the school. In addition, the findings will assist teachers in handling any problematic behavior in the child. 
Finally, the findings in this study differ in certain aspects from the findings in previous studies. The Chinese parents in this study were perceived to be low in demandingness as well as responsiveness and there was no difference between Chinese and Malay parenting practices. On the other hand, previous findings show Chinese parents were high in demandingness and low in responsiveness. However, the findings for Chinese fathers in this study were similar to those found in the literature where they were perceived higher in demandingness compared to mothers. As for the Malays, the findings on Malay parents had enlightened us on the parent-child relationship that had not been discussed in detail in previous studies. Even though the findings had been confined to a school, it had shown the low involvement of Malay parents in terms of their demandingness and responsiveness towards children. Thus, the findings in this study not only provide a useful guide in implementing a parenting course but should also be looked upon as an initial step into further research into other areas of parenting that could answer some of the problematic behaviors that exist among students in the school.

\section{REFERENCES}

Ary, D., Jacobs, L. C., \& Razavieh, A. (2002). Introduction to Research in Education. Australia: Wadsworth Thompson Learning.

Awang Koding Che Tom \& Tengku Sarina Tg. Kassim. (2003). Peranan institusi keluarga dalam membentuk kecemerlangan pendidikan (The role of family institution in the development of educational excellence). Paper presentation at the Persidangan Psikologi Malaysia 2003. "Peranan Psikologi Dalam Pendidikan" 9-11 Mei 2003, City Bayview Hotel, Langkawi Kedah Darul Aman.

Azizan Lebai Nordin. (2003). Penglibatan ibu bapa dalam pendidikan anak-anak anak
(Parental involvement in children's education). Paper presentation at the Persidangan Psikologi Malaysia 2003. "Peranan Psikologi Dalam Pendidikan" 9-11 Mei 2003, City Bayview Hotel, Langkawi Kedah Darul Aman.

Baumrind, D. (1967). Child care practices anteceding three patterns of pre-school behavior. Genetic Psychology Monographs, 75: 43-88.

Baumrind, D. (1971). Current patterns of parental authority. Developmental Psychology Monograph, 4 (1, part 2).

Best, D. L., \& House, A.S. (1994). Parent-child interactions in France, Germany, and Italy: The effects of gender and culture. Journal of Cross-Cultural Psychology, 25 (2): 181-194.

Block, J. H. (1983). Differential premises arising from differential socialization of the sexes: Some conjectures. Child Development, 54 (6): 1335-1354

Cohen, L., Manion, L., \& Morrison, K. ( $5^{\text {th }}$ ed.). (2001). Research Methods in Education. London: Routledge Falmer. p. 318.

Cooper, H., Kristina, J., Barbara, N., \& Lindsay, J. J. (2001). A model of homework's influence on the performance evaluations of elementary school students. Journal of Experimental Education, 69(2): 181200.

Epstein, J. L. (1995). School-Family-Community Partnerships: Caring for the Children we Share. Phi Delta Kappan 76 (9): 701712.

Fatimah Abdullah, Khaizir Ismail, \& Mustafa Omar. (2003). Keluarga sebagai rakan kongsi dalam pendidikan((Family partnership in education). Paper presentation at the Persidangan Psikologi Malaysia 2003. "Peranan Psikologi 
Dalam Pendidikan" 9-11 May 2003, City Bayview Hotel, Langkawi Kedah Darul Aman.

Fatimah Yusooff \& Azman Ahmad. (2003). Hubungan kefungsian keluarga dengan personaliti: satu kajian di kalangan remaja bermasalah (Relationship between family function and personality: A study among high-risk adolescents). Paper presentation at the Persidangan Psikologi Malaysia 2003. "Peranan Psikologi Dalam Pendidikan" 9-11 May 2003, City Bayview Hotel, Langkawi Kedah Darul Aman.

Hair, F. H., Anderson, R. E., Tatham, R. L., \&

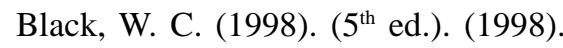
Multivariate Data Analysis. PrenticeHall International, Inc.

Halle, T. G., Kurtz-Costes, B., \& Mahoney, J. (1997). Family influences on school achievement in low-income, African American children. Journal of Educational Psychology, 89 (3): 527537.

Hanson, M. J., \& Lynch, E. W. (1990). Honoring the cultural diversity of families when gathering data. Topics in early Special Education, 90(10): 112-132.

Hong, E., \& Lee, Kit-Hung. (2000). Preferred homework style and homework environment in high-versus lowachieving Chinese student. Educational Psychology, 20(2): 125-138.

Julian, T. W., McKenry, P. C., \& McKelvey, M. W. (1994). Cultural variations in parenting, Family Relations, 43: 30-37.

Kadir Dikoh \& Salina Abdullah. (2002, August 26). Kerajaan dalam dilema tentukan peranan Wanita (The dilemma of the government in specifying the role of women). Berita Harian, p. 2.
Kaplan, D., Liu, X., \& Kaplan, H. B. (2000). Family structure and parental involvement in the intergenerational parallelism of school adversity. Journal of Educational Research, 93(4): 235245.

Lamborn, S. D., Mounts, N. S., Steinberg, L., \& Dornbusch, S. M. (1991). Patterns of competence and adjustment among adolescents from authoritative, authoritarian, indulgent, and neglectful families. Child Development, 62: 10491065.

Lokman Ismail. (2001, July, 30). Sikap ibu bapa menyebabkan pelajar melakukan jenayah (The attitude of parents have caused delinquency among students). Berita Harian, p.7.

Loong Caesar. (2002, August 4). Re-examining core values and assessing our role in promoting a caring society. New Sunday Times, p. 11.

Lytton, H., \& Romney, D. M. (1991). Parents' differential socialization of boys and girls: a meta-analysis. Psychological Bulletin, 109: 267-296.

Maccoby, E. E., \& Martin, J.A. (1983). Socialization in the context of the family: Parent-child interaction. In P. H. Mussen (Ed.), Handbook of Child Psychology, 4: 1-101. New York: Wiley.

Mason, E.J., \& Bramble, W.J. (1997). Research in Education and the Behavioral Sciences: Concepts and Methods. Madison, WI Dubuque: Brown \& Benchmark, p. 216.

McBride-Chang, C., \& Chang, L. (1998). Adolescent-parent relations in Hong Kong: Parenting styles, emotional autonomy, and school achievement. Journal of Genetic Psychology, 159 (4): 421-437. 
Mohd Zamir Bahall. (2002, Julai 14). Rahsia membentuk keluarga bahagia (The secret of creating a harmonious family). Berita Minggu, p. 14.

Nik Safiah Karim. (2002, August 26). Tema Hari Wanita mempunyai implikasi kepada Masyarakat (The theme for Women's Day have an implication on the society). Berita Harian, p. 12.

Noller, P., \& Taylor, T. (2001). Parent education and family relations. Family Relations :196-200.

Noormala Mohd Daud. (2002, August 7). Keluarga bahagia asas masyarakat sejahtera (A harmonious family is the root to the well-being of a society), Berita Harian, p. 26.

Noran Fauziah Yaakub, Jahara Hashim, Nuraini Yusoff., \& Zahyah Hanafi. (2000). Parents of children at risk: Case of a rural Malaysian elementary school. Paper presented at the $10^{\text {th }}$ Annual International Roundtable on School, Family, and Community Partnerships, Chateau LeMoyne Hotel, New Orleans.

Nunnally, J. C. (1978). Psychometric Theory. New York: McGraw-Hill Book Company, p. 14

Paulson, S. E. (1994a). Relations of parenting style and parental involvement with ninthgrade students' achievement. Journal of Early Adolescence, 14: 250-276.

Paulson, S. E. (1994b). Construction and validation of parenting style and parental involvement scales. Ball State University.

Paulson, S. E., Hill, J. P., \& Holmbeck, G. N. (1991). Distinguishing between perceived closeness and parental warmth in families with seventh grade boys and girls. Journal of early Adolescence, 11(2): 276-293.

Paulson, S. E., \& Sputa,C. L. (1996). Patterns of parenting during adolescence: perceptions of adolescents and parents. Adolescence, 31 (122): 369-382.

Pipp, S., Shaver, P., Jennings, S., Lamborn, S., \& Fischer, K. W. (1985). Adolescents' theories about the development of their relationships with parents. Journal of Personality and Social Psychology, 48 (4): 991-1001.

Rohaniza Idris. (2002, August 5). Masyarakat perlu perbaiki institusi keluarga (The society needs to improve the family institution). Berita Harian, p. 6.

Saufi Hamzah. (2002, August, 18). Keluarga bahagia tunjang negara dinamik (A harmonious family is the pillar to a dynamic country), Berita Harian, p. 2.

Schwarz, J. C., Barton-Henry, M. L., \& Pruzinsky, T. (1985). Assessing child-rearing behaviors: A comparison of ratings made by mother, father, child and sibling on the CRPBI. Child Development, 56: 462479.

Seginer, R. (1983). Parents' educational expectations and children's academic achievement: A literature review. Merrill-Palmer Quarterly, 29: 1-23.

Shek, D. T. L. (1999). Perceptions of family functioning among Chinese parents and their adolescent children. American Journal of Family Therapy, 27(4): 303315.

Shek, D. T. L. (1998). Adolescents' perceptions of paternal and maternal parenting styles in a Chinese context. Journal of Psychology 132 (5): 527-538. 
Shek, D. T. L. (2000). Differences between fathers and mothers in the treatment of, and relationship, with their teenage children: perceptions of Chinese adolescents. Adolescence, 35: 135-175.

Steinberg, L., Dornbusch, S. M., \& Brown, B. B. (1992). Ethnic differences in adolescent achievement: An ecological perspective. American Psychologist, 47: 723-729.

Steinberg, L., Mounts, N., \& Lamborn, S., \& Dornbusch, S. (1991). Authoritative parenting and adolescent adjustment across various ecological niches. Journal of Research on Adolescence, 1: 19-36.

Sumitha Martin. (2002, July 3). Let teacher talk to parents. New Straits Times, p. 10.www.ilo.org/public/english/ employment/gems/eeo/law/malaysia/ mnu.htm). The Ministry of Women and Family Development (2002).

Vitulli, W. F., \& Richardson, D. K. (1998). College students' attitudes toward relationships with parents: a five-year comparative analysis. Journal of Genetic Psychology, 159(1): 45-53.

Wan Halim Othman. (1993). Psikologi Melayu. Kuala Lumpur: Dewan Bahasa dan Pustaka

Wee Beng Neo, Jennifer. (1999). Perceptions of primary schools' headmasters and teachers towards the concepts, importance, and practices of school and family partnerships. Unpublished doctoral dissertation, Universiti Putra Malaysia, Serdang, Malaysia. 